\title{
Article \\ Effect of Melt Overheating on Structure and Mechanical Properties of Al-Mg-Si Cast Alloy
}

\author{
Vladislav Deev ${ }^{1,2}$ (D) Evgeny Prusov ${ }^{3, *(D)}$, Ernst Ri ${ }^{4}$, Olga Prihodko ${ }^{5}$, Svetlana Smetanyuk ${ }^{6}$, Xizhang Chen ${ }^{7,8}$ (D) \\ and Sergey Konovalov 7,8 (D)
}

1 School of Mechanical Engineering and Automation, Wuhan Textile University, Wuhan 430073, China; deev.vb@mail.ru

2 Department of Metal Forming, National University of Science and Technology MISiS, 119049 Moscow, Russia

3 Department of Functional and Constructional Materials Technology, Vladimir State University Named after Alexander and Nikolay Stoletovs, 600000 Vladimir, Russia

4 Department of Foundry Engineering and Metal Technology, Pacific National University, 680042 Khabarovsk, Russia; erikri999@mail.ru

5 Department of Quality Management, Siberian State Industrial University, 654007 Novokuznetsk, Russia; prihodko_og@mail.ru

6 Foundry Department, Siberian State University, 660041 Krasnoyarsk, Russia; smetanyuk.sv@mail.ru

7 School of Mechanical and Electrical Engineering, Wenzhou University, Wenzhou 325035, China; chenxizhang@wzu.edu.cn (X.C.); ksv@ssau.ru (S.K.)

8 Department of Metals Technology and Aviation Materials, Samara National Research University, 443086 Samara, Russia

* Correspondence: eprusov@mail.ru

Citation: Deev, V.; Prusov, E.; Ri, E.; Prihodko, O.; Smetanyuk, S.; Chen,

X.; Konovalov, S. Effect of Melt

Overheating on Structure and

Mechanical Properties of Al-Mg-Si

Cast Alloy. Metals 2021, 11, 1353.

https://doi.org/10.3390/

met11091353

Academic Editor: Babak

Shalchi Amirkhiz

Received: 21 July 2021

Accepted: 26 August 2021

Published: 28 August 2021

Publisher's Note: MDPI stays neutral with regard to jurisdictional claims in published maps and institutional affiliations.

\section{Copyright: (c) 2021 by the authors.} Licensee MDPI, Basel, Switzerland. This article is an open access article distributed under the terms and conditions of the Creative Commons Attribution (CC BY) license (https:// creativecommons.org/licenses/by/ $4.0 /)$.

\begin{abstract}
The paper discusses the complex effect of melt overheating with subsequent fast cooling down to the pouring temperature on the crystallization process, microstructure and mechanical properties of Al-Mg-Si aluminum alloy. The results obtained facilitated the establishment of rational modes of melt overheating, leading to a significant change in the dispersion and morphology of structural components. In particular, with an increase in the melt overheating temperature to $900{ }^{\circ} \mathrm{C}$ with holding and subsequent rapid cooling to the casting temperature, a decrease in the average size of dendritic cells of the aluminum solid solution from $39 \mu \mathrm{m}$ to $13 \mu \mathrm{m}$ was observed. We also noticed the refinement of eutectic inclusions of the $\mathrm{Mg}_{2} \mathrm{Si}$ phase with compact morphology. An increased level of mechanical properties was noted; the maximum values of tensile strength and elongation reached $228 \mathrm{MPa}$ and $5.24 \%$, respectively, which exceeded the initial values by $22.5 \%$ and $52.3 \%$, correspondingly. The microhardness of the aluminum solid solution sequentially increased from 38.21 to $56.5 \mathrm{HV}$ with an increase in the temperature during melt overheating. According to the EDS linear scanning, an increase in the superheat temperature of the melt is accompanied by an increase in the degree of saturation of the solid solution with magnesium.
\end{abstract}

Keywords: Al-Mg-Si alloy; melt overheating; superheat treatment; microstructure; grain refinement; mechanical properties

\section{Introduction}

It is well known that the quality of cast products made of aluminum alloys is largely determined by their structure. In particular, the mechanical and operational properties of aluminum alloys significantly depend on such structural factors like morphology, size, and distribution of structural components, including grains of an aluminum $\alpha$-solid solution and various primary crystallizing phases [1-3]. In this regard, the formation of a finegrained structure in castings is one of the ways to increase their properties and improve the quality of products from aluminum alloys [4-6]. The problem of creating resource-efficient technologies for modifying casting alloys is exacerbated by the fact that the growing requirements for castings in terms of physical, mechanical, and operational properties have 
to be met under conditions of a continuous increase in the amount of using secondary charge materials [7]. These trends in the use of scrap and waste as a charge materials not only reduce the cost of cast materials, but also contribute to reduce the extraction of virgin ores on a global scale, preserving reserves of natural raw materials [8].

Advances in the development of the theory of the structure of metal melts contributed to the development of new promising methods for processing melts, which make it possible to achieve a modified structure without introducing expensive (and not always effective and convenient in use) additive elements [9]. These methods include various physical effects on metal melts during melting and crystallization, such as overheating (so called thermal-temporal and thermal-rate treatment) [10-12], electrical and electromagnetic treatment $[13,14]$, ultrasonic treatment $[15,16]$, vibration treatment [17] and many others. In industrial conditions, from the point of view of technological implementation, the most convenient treatment is the processing of melts during melting [18].

Numerous studies confirm the relationship between melt structure and modified alloy structures in the solid state. At present, it is generally accepted that atomic clusters are retained in the structure of metal melts under certain conditions $[19,20]$. Recently, there have been many theoretical concepts and hypotheses about the structural components in melts, all of them have one or another argument in their favor; however, there is still no unified and universal concept of the structure of metallic melts [21]. The same applies to the influence of the high-temperature state of the melt on the structure of alloys in the as-cast state. It is assumed that overheating of melts to high temperatures increases the degree of their homogeneity due to the intensification of the thermal motion of atoms, which leads to a decrease or destruction of atomic clusters [22,23].

Thus, the search for rational parameters for the processing of melts by overheating is closely related to the issues of the influence of melt homogeneity on solidification microstructure and properties. Investigations in this direction have been actively carried out since the 1970s. Recent studies have shown that the destruction of microinhomogeneities during overheating of metal melts leads to an increase in supercooling before the start of nucleation [24]. In particular, in [25], direct experimental confirmation of the effect of the melt superheating on the nucleation undercooling was given, and it was shown that an increase in the overheating temperature of melts of the Al-Si system significantly reduces the size of primary crystals. It was shown that an increase in undercooling could lead to the activation of small inclusions, which under normal conditions do not participate in nucleation processes, as well as to homogeneous nucleation throughout the entire volume of the undercooled liquid.

The high-temperature type of short-range order (SRO) structure of the melt can be fixed by rapid cooling of the melt before pouring [26], since the rate of structural transformations in the liquid phase is rather low, despite the relatively high rates of diffusion processes. Due to the low rate of structural changes in the liquid phase, rapid cooling of the melt can largely suppress the transformation of clusters and other various atomic groups [27,28]. Due to this, by the use of overheat treatment with fast melt cooling, it is possible to fix to a certain extent the high-temperature type of structure of the liquid phase at the time of pouring the melt into the mold. Thus, obtaining a fine-grained structure of a cast alloy by high-temperature overheating followed by fast melt cooling is an important promising reserve for increasing the level of mechanical and operational properties of castings from various alloys.

In recent years, the method of melt overheating has been most successfully tested on aluminum alloys of various systems. Confirmed effects of such processing include, for example, the columnar to equiaxed transition in $\mathrm{Al}-\mathrm{Cu}$ and $\mathrm{Al}-\mathrm{Cu}-\mathrm{Si}$ alloys [29], a significant refinement of grains of the primary solid solution in hypoeutectic Al-Si alloys [30] and primary silicon crystals in hypereutectic Al-Si alloys [31]. A transition from dendritic grains to globular grains was also noted during thermal-rate processing of the aluminum alloy Al-9Si-0.5Mg [32]. It was observed that superheat treatment helped to reduce the harmful effects of iron impurities in Al-Si alloys due to its transfer to a more favorable 
morphology [27]. Certain successes were achieved in the modification of magnesium-based alloys by melt overheating [33]. However, the literature contains very limited information on the use of melt overheating technique on alloys of the Al-Mg and Al-Mg-Si systems. At the same time, casting alloys based on the Al-Mg-Si system, belonging to the AA 5xx.x series (Aluminum Association, Arlington, VA, USA), have significant potential for application in the automotive, shipbuilding and aerospace industries, therefore, the search for effective ways to obtain a modified structure in them is an industrially significant task [34]. At present, alloys of this system are mainly modified with expensive additives of transition metals such as $\mathrm{Zr}, \mathrm{Hf}, \mathrm{Nb}$, Sc, etc. [35]. Nonetheless, these methods do not always lead to the desired result and entail technological difficulties associated with the need for accurate metering of the amount of modifier when introduced into the melt. It also produces undesirable accumulation of modifiers in the alloys in the form of impurities in the event of the involvement of scrap and waste of these alloys as the secondary materials with multiple reuse.

Thus, the aim of this work is to study the effect of different levels of the melt overheating with subsequent fast cooling down to the pouring temperature on the microstructure and mechanical properties of cast aluminum alloys based on the Al-Mg-Si system (for example, of the industrial aluminum casting alloy of the AA 511 grade).

\section{Materials and Methods}

Pure components were used as initial materials for the preparation of experimental alloys: aluminum $(\geq 99.99 \% \mathrm{Al})$, magnesium $(\geq 99.9 \% \mathrm{Mg})$, silicon $(\geq 99.0 \% \mathrm{Si})$. The chemical composition of the alloys was determined using ARL ADVANT'X X-ray fluorescence spectrometer (Thermo Fisher Scientific, Waltham, MA, USA). The standard chemical composition of the alloy and the actual averaged composition of the samples obtained at different temperatures of melt overheating are presented in Table 1.

Table 1. The standard and averaged actual chemical compositions of 511.0 alloy samples obtained at different levels of melt overheating (Aluminum Association, USA).

\begin{tabular}{cccccccccc}
\hline Component & Al & Mg & Si & Fe & Cu & Mn & Zn & Ti & Others \\
\hline Standard, wt. $\%$ & Bal. & $3.5-4.5$ & $0.3-0.7$ & $\leq 0.5$ & $\leq 0.15$ & $\leq 0.35$ & $\leq 0.15$ & $\leq 0.25$ & $\leq 0.15$ \\
Actual (sample at $750^{\circ} \mathrm{C}$ ), wt. $\%$ & Bal. & 4.352 & 0.495 & 0.034 & 0.030 & 0.071 & 0.012 & 0.060 & $<0.15$ \\
Actual (sample at $800^{\circ} \mathrm{C}$ ), wt. $\%$ & Bal. & 4.415 & 0.489 & 0.043 & 0.038 & 0.068 & 0.011 & 0.045 & $<0.15$ \\
Actual (sample at $850^{\circ} \mathrm{C}$ ), wt. $\%$ & Bal. & 4.433 & 0.410 & 0.032 & 0.039 & 0.074 & 0.012 & 0.058 & $<0.15$ \\
Actual (sample at $900^{\circ} \mathrm{C}$ ), wt. $\%$ & Bal. & 4.305 & 0.444 & 0.036 & 0.037 & 0.076 & 0.012 & 0.049 & $<0.15$ \\
\hline
\end{tabular}

Melting was carried out in a shaft electric resistance furnace with a crucible capacity of $20 \mathrm{~kg}$ for aluminum. Before melting, all charge materials were thoroughly cleaned and heated to a temperature of $150{ }^{\circ} \mathrm{C}$. After melting the aluminum, gaseous technical argon $(99.98 \% \mathrm{Ar})$ was fed into the furnace at the mirror of the melt, and the supply was continued until the end of melting. At a temperature of $720-740{ }^{\circ} \mathrm{C}$, silicon was added to the melt according to the calculation of the charge. After complete dissolution of silicon, magnesium wrapped in aluminum foil was added at $720-740^{\circ} \mathrm{C}$ and thoroughly mixed with a graphite rod. The melt was kept for $10 \mathrm{~min}$ at a given superheat temperature (750, 800,850 and $900{ }^{\circ} \mathrm{C}$ ). Upon completion of the exposure, rapid cooling to the pouring temperature was carried out by adding unheated aluminum ingots into the melt. In all series of experiments, samples were obtained at the same pouring temperature of $720{ }^{\circ} \mathrm{C}$ and mold preheating temperature of $200^{\circ} \mathrm{C}$. The cooling rate to the casting temperature was $70-90^{\circ} \mathrm{C} / \mathrm{min}$. Immediately after reaching the required temperature, the melt was poured into a cylindrical steel mold with an inner diameter of $30 \mathrm{~mm}$ and a height of $100 \mathrm{~mm}$. Samples were cut from the obtained ingots to study the microstructure and distribution of alloying elements. Samples for mechanical tests were machined from ingots cast into a steel mold with a diameter of $35 \mathrm{~mm}$ and a height of $220 \mathrm{~mm}$. 
The study of the microstructure of the samples was carried out on a digital metallographic microscope MICRO 200 (Optoelectronic Systems OJSC, Minsk, Belarus) on thin sections in the as-cast condition. To ensure comparability, all samples obtained at different temperatures of melt overheating were cut at the same distance of $15 \mathrm{~mm}$ from the bottom of the ingot and prepared in accordance with standard metallographic sample preparation procedures. The IM4000 Ion Milling System (Hitachi, Tokyo, Japan) was used to prepare the sections. Metallographic images were taken at the same distance from the edge of the sample, which was the same for all studied samples. Average sizes of dendritic cells were quantified using the Abrams circular intercept technique according to ASTM E112. For measurements, ImageJ v.1.53 software (NIH, Bethesda, MD, USA) was used. To quantify the average sizes of dendritic cells, at least five analysis zones were selected for each sample.

The study of microhardness was carried out on samples prepared for metallographic observations. A Shimadzu HMV-G device (Shimadzu, Kyoto, Japan) was used to measure the microhardness. Microhardness indices were calculated according to the standard procedure. The nominal value of the test force was $9.807 \mathrm{mN}$ (HV0.001), exposure $15 \mathrm{~s}$, a Vickers-type diamond pyramid was used as an indenter, and measurements were made in accordance with ISO 6507-1: 2018. Each reported microhardness value is the arithmetic mean of at least ten measurements taken.

The tensile strength was determined at a speed of $3 \mathrm{~mm} / \mathrm{min}$ on samples with a working section length of $150 \mathrm{~mm}$ and a diameter of $15 \mathrm{~mm}$ using a Shimadzu AG-X Plius machine (Shimadzu, Kyoto, Japan). The measured values in each case are obtained as average over the test results of five specimens that do not have any obvious casting defects on the fracture surface.

X-ray spectral microanalysis to determine the content of elements in various structural components of alloy was carried out on an SU-70 apparatus (Hitachi, Tokyo, Japan) with attachments for energy-dispersive analysis (Thermo Fisher Scientific Ultra Dry), wave elemental micro-X-ray spectral analysis (Thermo Fisher Scientific MagnaRay) and microphase analysis by reflected diffraction electrons (Thermo Scientific QuasOR). The microheterogeneity of the distribution of elements in the metal base in selected areas of the sample in reflected electrons in phases along the selected profiles was estimated.

Thermodynamic calculations of the equilibrium phase diagram of Al-Mg-Si and prediction of the evolution of the fraction of solid phases during crystallization were performed in the Thermo-Calc software package (version 3.1, TTAL5 Al-based alloy thermodynamic database, Thermo-Calc Software AB, Stockholm, Sweden) using the CALPHAD approach. Due to the fact that only pure components were used in the preparation of experimental alloys, the calculations did not consider the possible effect of low concentrations of impurity elements in the alloy.

\section{Results and Discussion}

As is known, AA 511 alloy is a low-concentrated alloy based on the Al-Mg-Si ternary system; therefore, the thermodynamic parameters of the components and formed phases in the equilibrium state are widely available and presented in the corresponding databases. Figure 1 shows the isothermal section of $\mathrm{Al}-\mathrm{Mg}$-Si phase diagram at $25^{\circ} \mathrm{C}$ in the $\mathrm{Al}$-rich corner and polythermal section at $0.5 \mathrm{wt} . \% \mathrm{Si}$ and up to $5.0 \mathrm{wt} . \% \mathrm{Mg}$. The dashed line Figure 1a indicates the standardized composition range of magnesium and silicon in AA 511 alloy. According to the thermodynamic calculations, in the cast state, the structure of the alloy in the considered range of concentrations of alloying elements after complete solidification should be represented by the phases $\mathrm{Al}_{3} \mathrm{Mg}_{2}+\mathrm{FCC}+\mathrm{Mg}_{2} \mathrm{Si}$. 


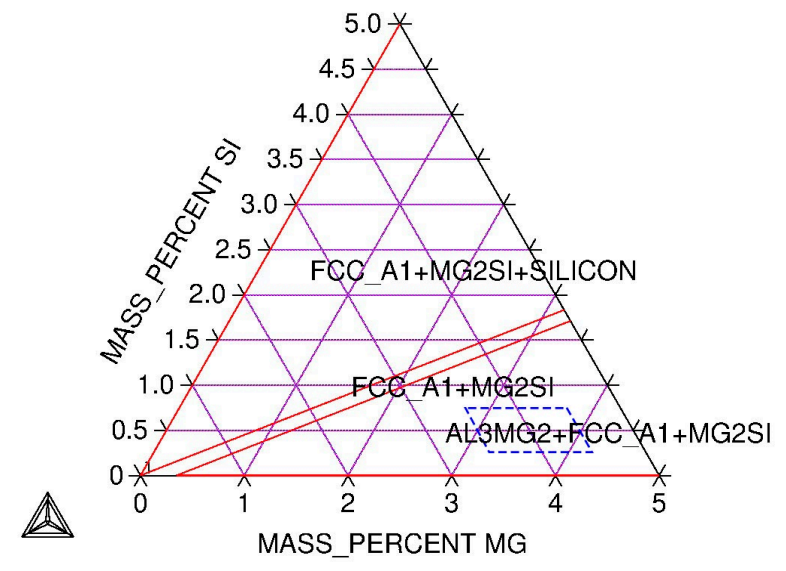

(a)

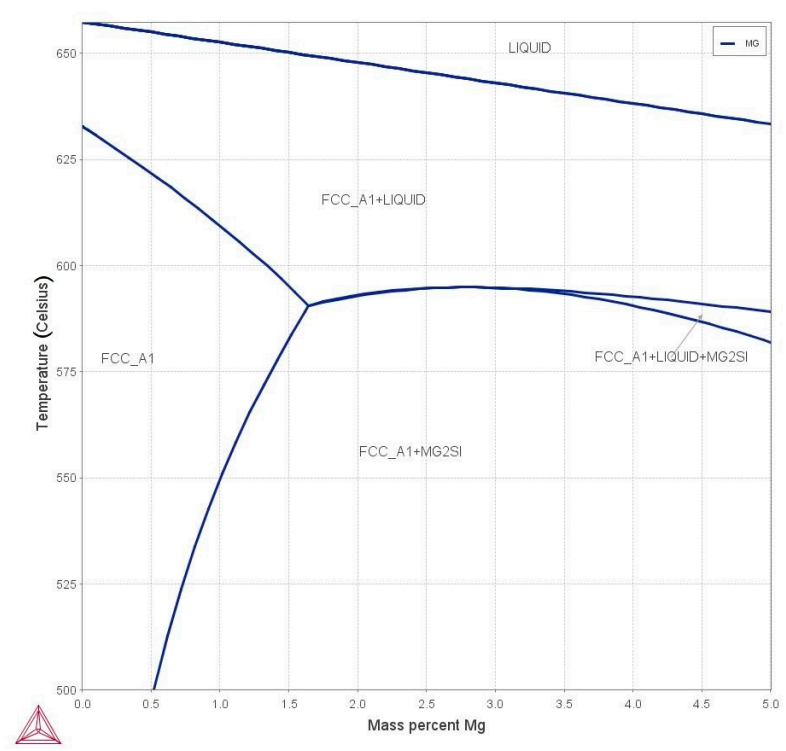

(b)

Figure 1. Calculated isothermal section of Al-Mg-Si phase diagram at $25{ }^{\circ} \mathrm{C}$ in the Al-rich corner (a) and polythermal section at $0.5 \mathrm{wt} . \% \mathrm{Si}$ and up to $5.0 \mathrm{wt} . \% \mathrm{Mg}(\mathbf{b})$.

To assess the change in the mass fraction of solid phases during the crystallization of the AA 511 alloy, calculations were performed based on the Scheil-Gulliver solidification model implemented in the Thermo-Calc program. The content of the main alloying elements in the alloy was taken according to the average value of the regulated concentration range. According to the solidification curve Figure 2, crystallization of an alloy containing $4.0 \mathrm{wt} . \% \mathrm{Mg}$ and $0.5 \mathrm{wt} . \% \mathrm{Si}$ begins at $638.1^{\circ} \mathrm{C}$ with the formation of dendrites of the $\alpha$-solid solution. The beginning of the formation of the $\mathrm{Mg}_{2} \mathrm{Si}$ phase corresponded to a temperature of $588.3{ }^{\circ} \mathrm{C}$. The second intermetallic phase $\mathrm{Al}_{3} \mathrm{Mg}_{2}$ precipitated at a temperature of $450^{\circ} \mathrm{C}$. It is obvious that the solidification of an alloy of this composition should end in the three-phase region ( $\mathrm{Al})+\mathrm{Mg}_{2} \mathrm{Si}+\mathrm{Al}_{3} \mathrm{Mg}_{2}$. Thus, during the thermal-rate processing of AA 511 alloy melts, an important task is to search for modes that provide a modifying effect on both the dendritic cells of the $\alpha$-solid solution and the excess phases of crystallization origin.

Representative metallographic images of the AA 511 alloy structure under various modes of melt heat treatment are shown in Figure 3. Metallographic studies of alloy samples in the as-cast state, obtained at different temperatures of melt overheating, confirmed the modifying effect on the dispersion and morphology of structural components in the $\mathrm{Al}-\mathrm{Mg}$-Si system. In particular, judging by the obtained micrographs, an increase in the overheating temperature of the melt was accompanied by the refining of dendrites of the aluminum solid solution and eutectic inclusions of the $\mathrm{Mg}_{2} \mathrm{Si}$ phase. Additionally, a change in the morphology of the $\mathrm{Mg}_{2} \mathrm{Si}$ from skeleton-like to a more compact one was also observed. Obviously, the best structural and morphological parameters of the processed alloys in the performed series of experiments were achieved at overheating temperature $900{ }^{\circ} \mathrm{C}$. 


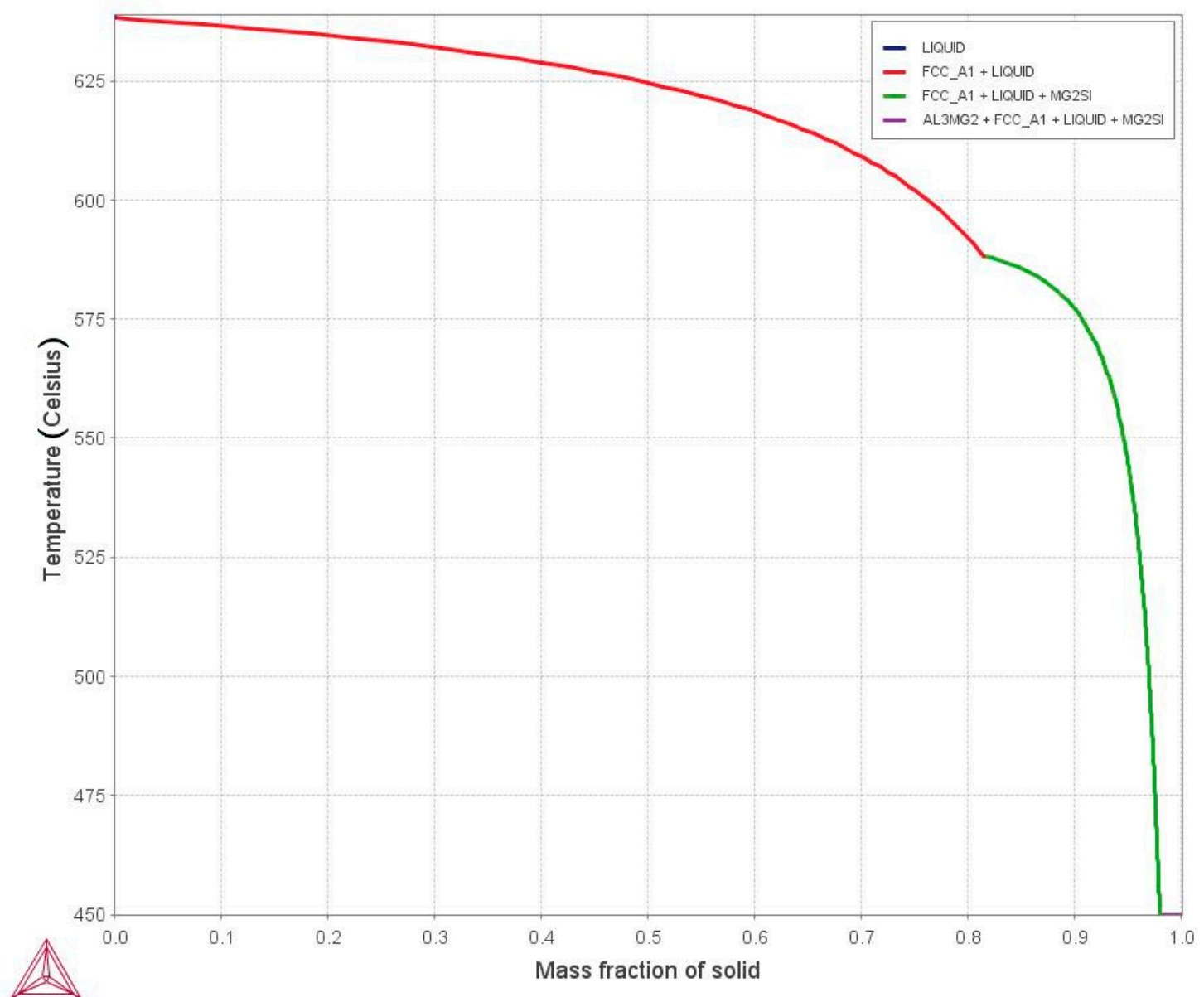

Figure 2. The calculated Scheil-Gulliver solidification diagram for AA 511 alloy at $4.0 \mathrm{wt}$.\% Mg and 0.5 wt. \% Si.

In the structure of the alloy obtained without melt overheating, the average size of dendritic cells was $39.12 \mu \mathrm{m}$. An increase in the overheating temperature during the melt processing to 800,850 and $900{ }^{\circ} \mathrm{C}$ was accompanied by a sequential decrease in the average size of dendritic cells to $22.06 \mu \mathrm{m}, 17.65 \mu \mathrm{m}$ and $13.01 \mu \mathrm{m}$, respectively.

For all melt treatment options, EDS line scans were used to study the distribution of alloying elements and impurities over the sample cross-section. Figure 4 shows the distribution of $\mathrm{Al}, \mathrm{Mg}, \mathrm{Si}$ and $\mathrm{Fe}$ in the cast samples of the AA 511 alloy at different temperatures of melt overheating in comparison with the corresponding SEM images for which they were obtained.

The analysis of the SEM microstructures in reflected electrons showed that the alloy of AA 511 grade in the cast state consisted of an $\alpha$-solid solution of magnesium in aluminum and a pseudo-eutectic, in which $\mathrm{Si}$ and impurity elements (in particular, $\mathrm{Fe}$ ) were dissolved. According to the results of the analysis of the elements in the structural components of AA 511 alloy, depending on the overheating temperature, it was shown that with an increase in the overheating temperature during isothermal holding of the melt, the solubility of $\mathrm{Mg}$ in the $\alpha$-solid solution over the cross section of the sample increases. In particular, in the initial sample, the averaged magnesium content in the $\alpha$-solid solution was $2.76 \pm 0.16 \mathrm{wt} . \%$. An increase in the overheating temperature to 800,850 , and $900{ }^{\circ} \mathrm{C}$ was accompanied by a sequential increase in the magnesium content in the $\alpha$-solid solution to $3.25 \pm 0.18 \mathrm{wt} . \%, 3.76 \pm 0.16 \mathrm{wt} . \%$, and $4.21 \pm 0.19 \mathrm{wt} . \%$, respectively. In this case, the overheating temperature during isothermal holding in the studied temperature range has practically no effect on the solubility of silicon in a solid solution. The average values of solubility were obtained for at least ten points of analysis. 


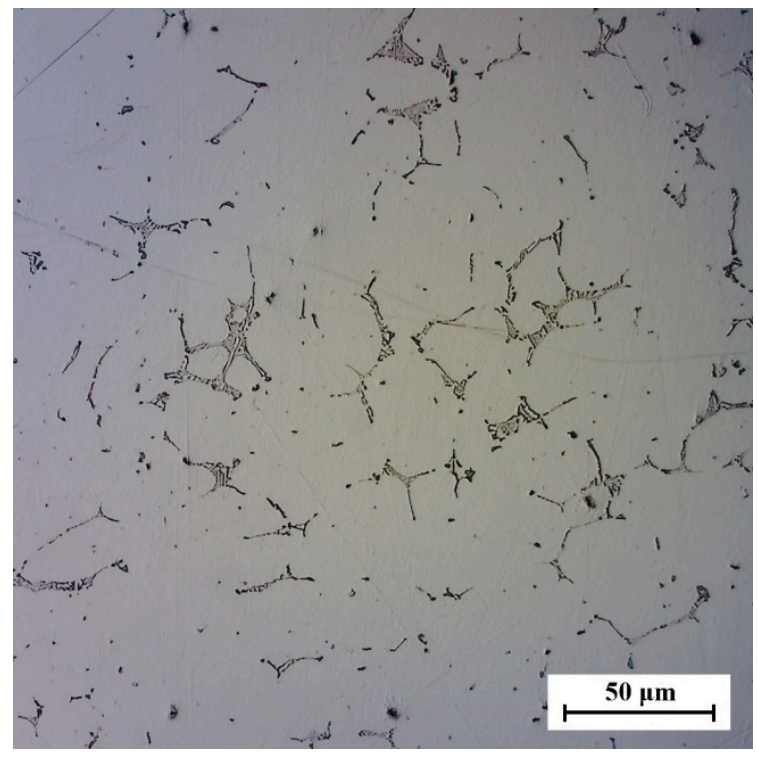

(a)

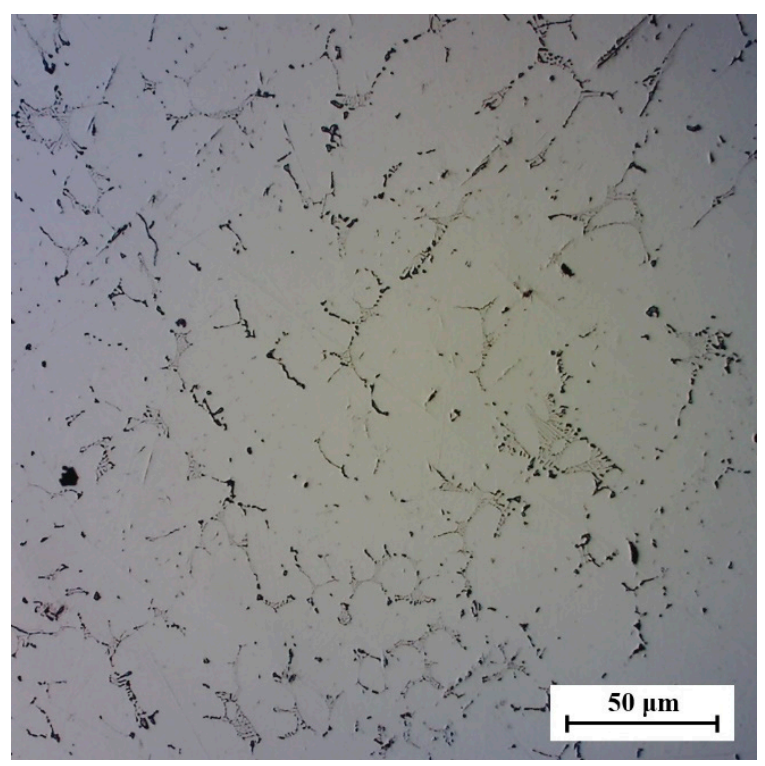

(c)

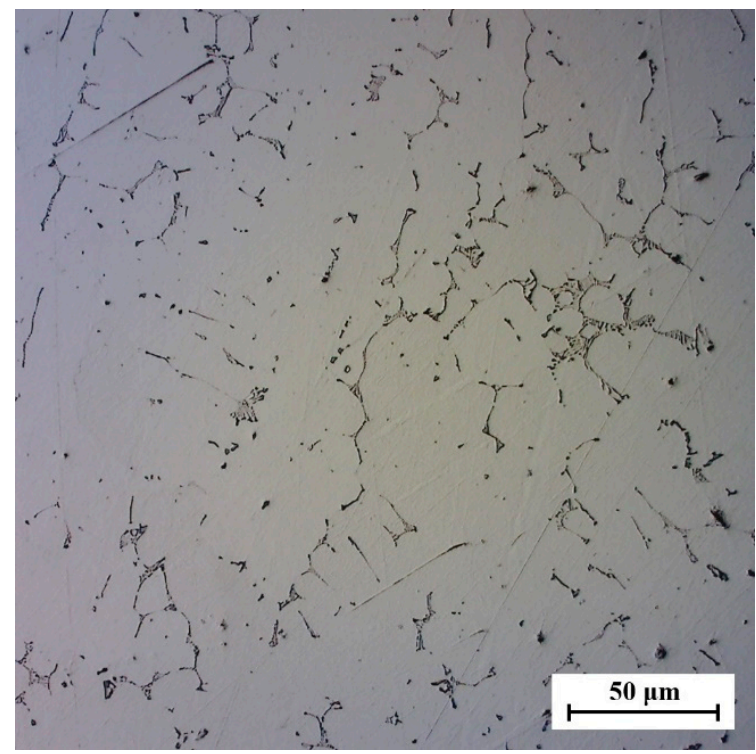

(b)

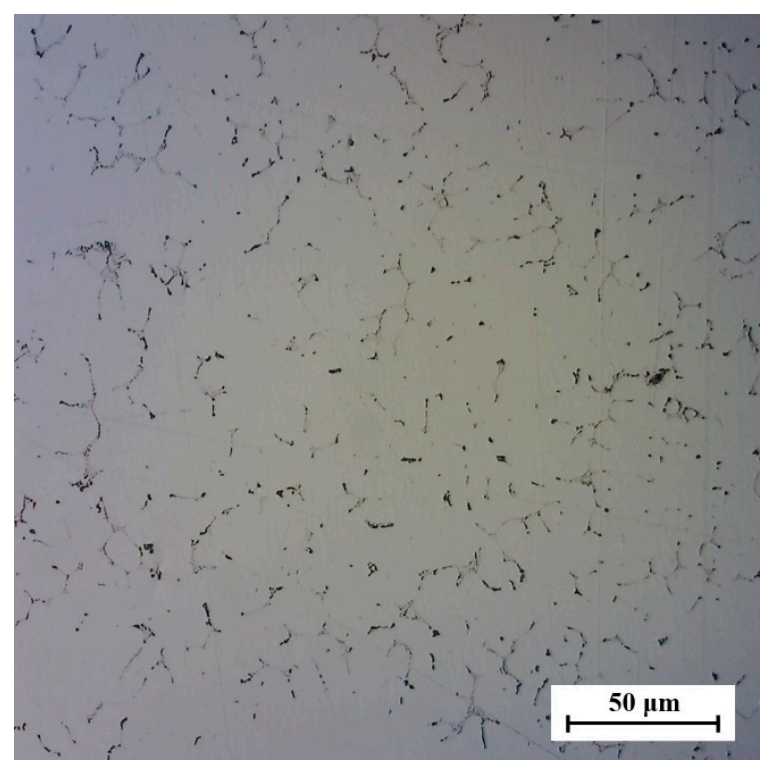

(d)

Figure 3. Optical microstructures of AA511 aluminum alloy at different levels of the melt overheating: 750 (a), 800 (b), 850 (c) and $900^{\circ} \mathrm{C}(\mathbf{d})$.

Figure 5 shows the averaged measured values of the microhardness of the structural components of the alloy samples obtained at different temperatures of melt overheating. It can be seen from the obtained measurements that the microhardness of the aluminum solid solution sequentially increased with an increase in the overheating temperature and demonstrated the highest value upon overheating to $900{ }^{\circ} \mathrm{C}(56.50 \pm 4.46 \mathrm{HV})$, while the microhardness of intergranular intermetallics remained practically at the same level upon overheating to 750,800 and $850{ }^{\circ} \mathrm{C}$, slightly increasing with overheating to $900{ }^{\circ} \mathrm{C}$ $(90.94 \pm 4.77 \mathrm{HV})$. The observed increase in the microhardness of the solid solution can be associated with an increased saturation of aluminum with alloying elements, primarily magnesium. At the same time, the melt overheating had no significant effect on the microhardness of the resulting intergranular intermetallics. 

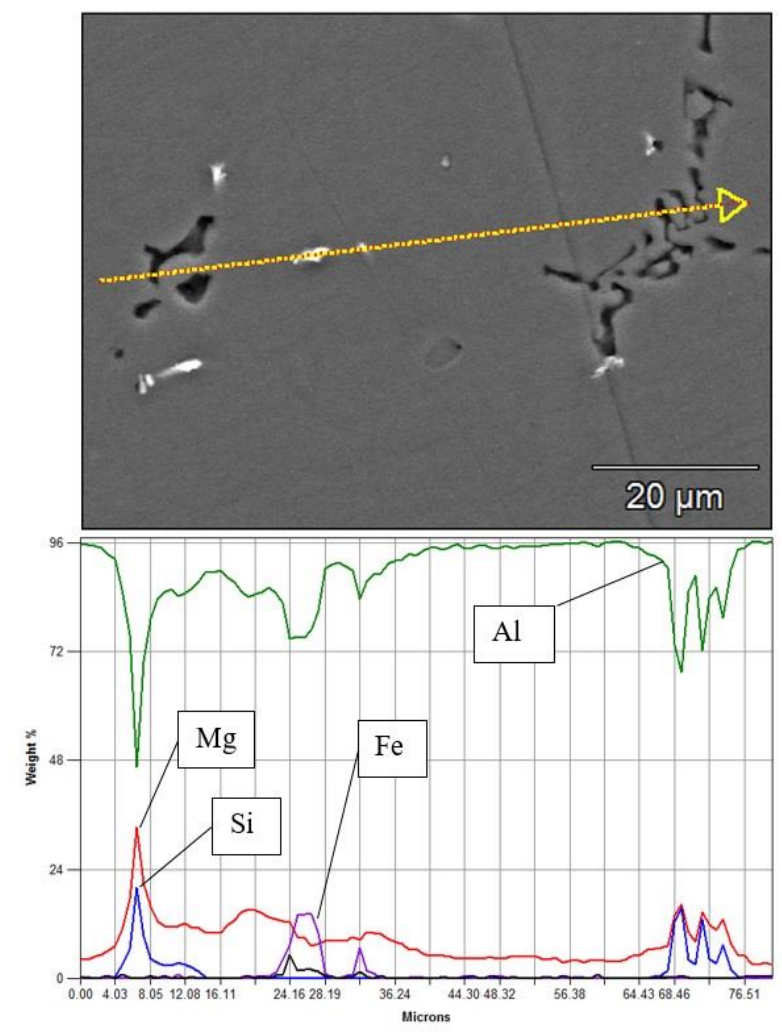

(a)

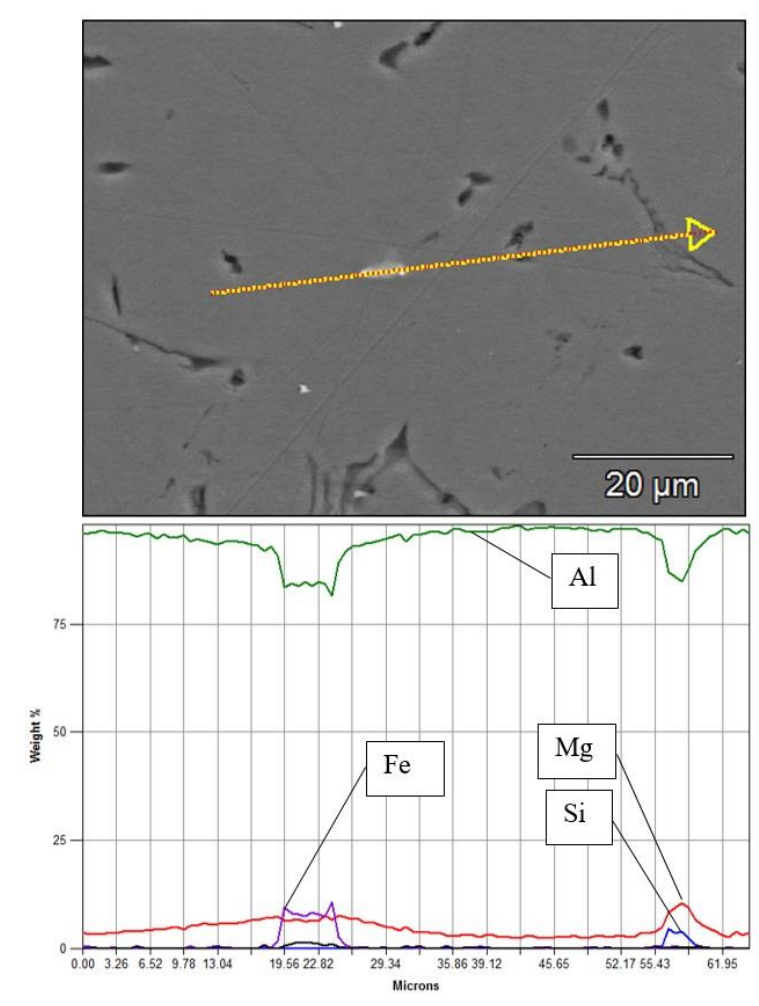

(c)
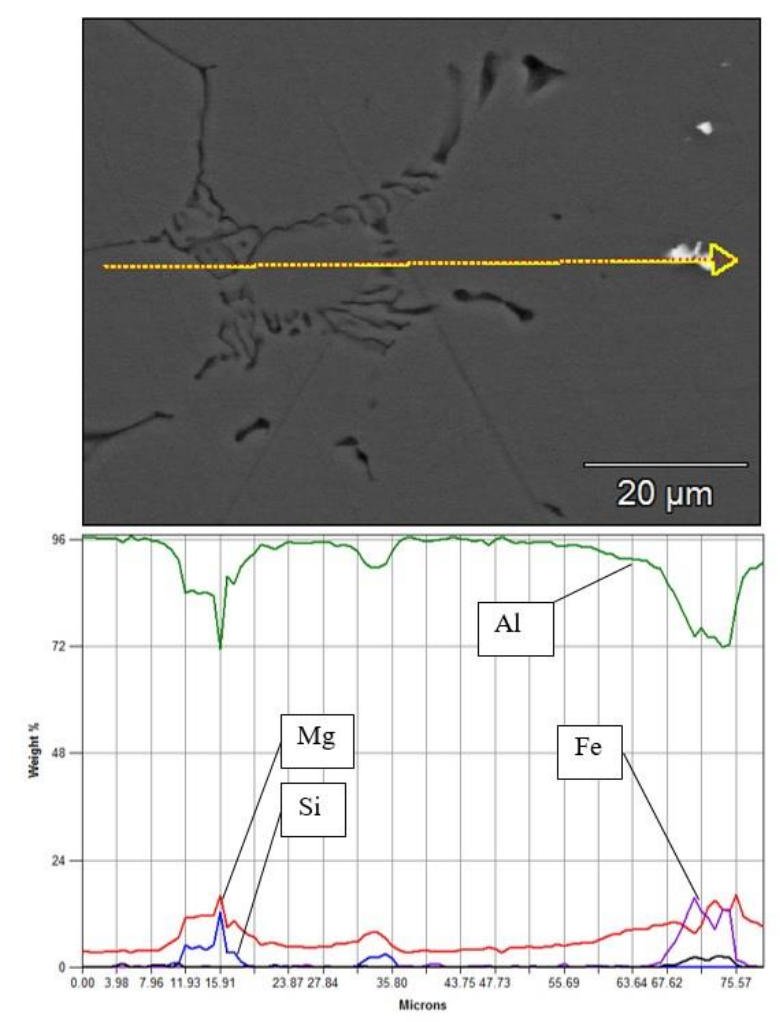

(b)
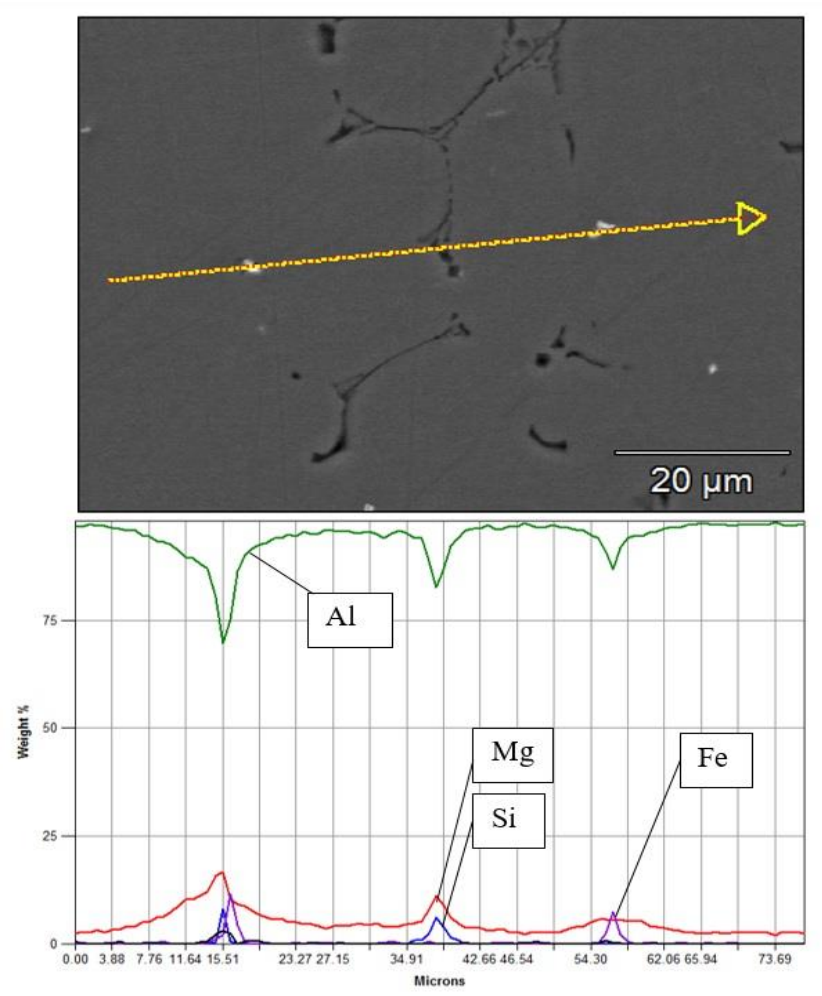

(d)

Figure 4. SEM images and corresponding EDS line scans of AA511 aluminum alloy showing element distributions at different levels of the melt overheating: 750 (a), 800 (b), 850 (c) and $900{ }^{\circ} \mathrm{C}(\mathbf{d})$. The line with an arrow in the SEM images shows the scanning direction. 


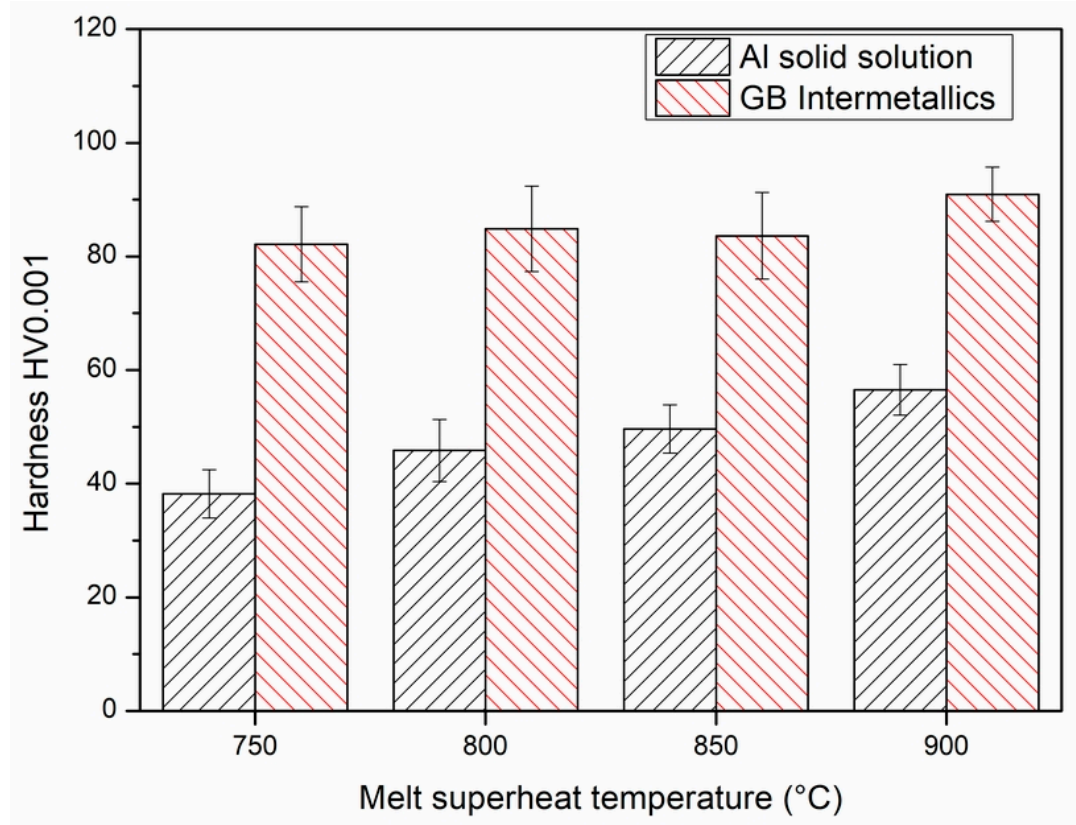

Figure 5. Microhardness of structural components of AA 511 aluminum alloy in as-cast state at different temperatures of the melt overheating.

Figure 6 shows the mechanical properties (tensile strength and elongation) of the AA 511 alloy at different overheating temperatures. The results demonstrated that when the melt overheated to $800{ }^{\circ} \mathrm{C}$, an increase in tensile strength was recorded on average from 186 to $200 \mathrm{MPa}$ with a slight increase in plasticity (from 3.44\% to 3.76\%). An increase in the overheating temperature to $850^{\circ} \mathrm{C}$ had practically no effect on the change in strength compared to overheating to $800{ }^{\circ} \mathrm{C}$; however, it significantly increased the ductility of the alloy (up to $4.27 \%$, which is $24 \%$ higher than in the initial state). The subsequent increase in the temperature of overheating of the melt to $900{ }^{\circ} \mathrm{C}$ lead to a significant increase in tensile strength (up to $228 \mathrm{MPa}$, which is $22.5 \%$ higher than the strength of the original alloy) and ductility of the alloy, the latter increasing by $52.3 \%$ in comparison with the untreated alloy. An increase in the mechanical properties of the alloy after the melt overheating with fast cooling down to the pouring temperature can be a consequence of the refining and compacting of particles of eutectic precipitates. The morphology of these inclusions will have a strong influence on the mechanical properties as well as the reduction in the average size of the dendritic cells. Thus, the melt overheating treatment can be considered as an effective way to increase the strength and plastic properties of alloys of the Al-Mg-Si system.

The mechanism of the influence of the processing of melts by overheating on the structure of the cast alloy is still controversial and is closely related to the concepts of the structure of metal melts. The effect of the melt overheating with subsequent fast cooling down to the pouring temperature on the structure and mechanical properties of alloys, apparently, can be defined by the fact that a fine-grained structure is formed due to a change in the degree of undercooling of a more homogeneous melt, which determines the character of crystallization of the melt. These assumptions are based on the concept of the initial structural and phase inhomogeneity of aluminum alloys of the Al-Mg-Si system, which are due to the coexistence of an $\alpha$-solid solution and intermetallic phases $\mathrm{Mg}_{2} \mathrm{Si}$ and $\mathrm{Al}_{3} \mathrm{Mg}_{2}$, as well as phases formed due to the presence of impurity elements. In a melt of this composition, microgroups of atoms can exist that retain the elements of the shortrange order structure, and are the carriers of the characteristics of the above-mentioned excess phases. Numerous studies on temperature dependences of density, viscosity, surface tension, resistivity and other structure-sensitive properties of metal melts indicated the occurrence of some structural rearrangements when overheated above the liquidus temper- 
ature to certain critical values [36-38]. After reaching the critical temperature, the values of which will depend on the chemical composition of the alloy, irreversible destruction of atomic segregations can occur and the melt approaches a microhomogeneous equilibrium state. Homogenization of the melt at a high superheat temperature is accompanied by dissolution of clusters, leading to higher undercooling [39]. Thus, an increase in the degree of microhomogeneity of the melt changes the thermodynamic conditions of crystallization, resulting in the production of an alloy with a more ordered phase and structural composition. In addition, an increase in undercooling leads to the formation of a supersaturated solid solution in terms of the content of alloying elements. With an increase in the overheating temperature, thermally-induced diffusion processes intensify contributing to a more uniform distribution of alloying elements [40] and thereby affecting undercooling.

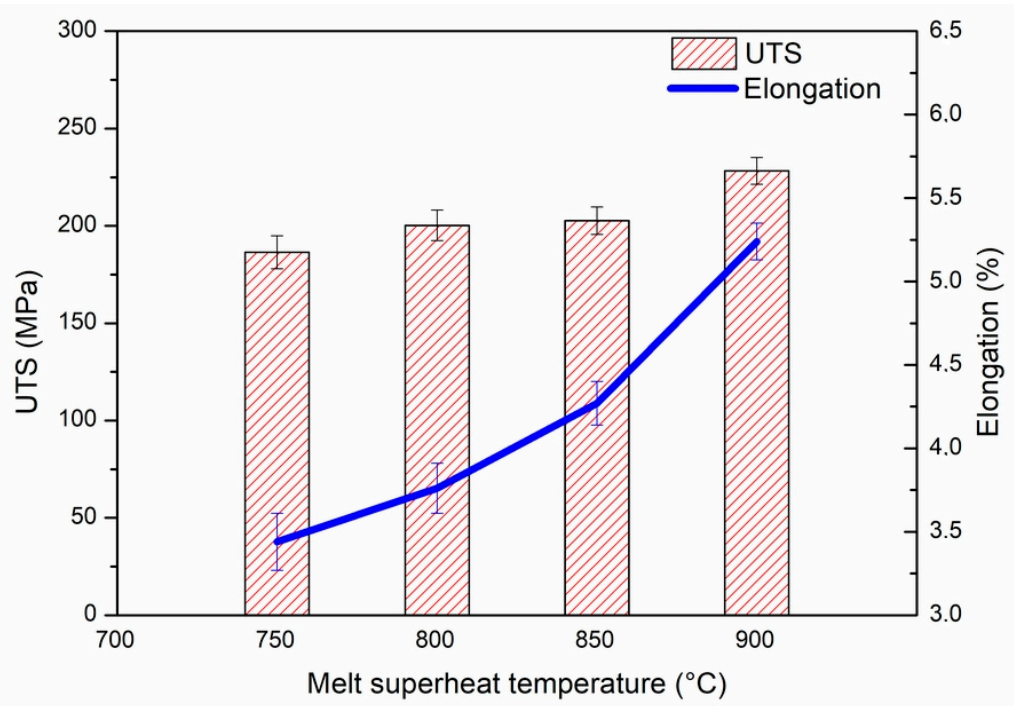

Figure 6. Tensile strength (MPa) and elongation (\%) of the AA 511 alloy in the as-cast state at different temperatures of melt overheating.

In addition to the described effects associated with high-temperature overheating and isothermal holding of the melt, in practice, the implementation of such treatment leads to an increase in the cooling rate of the melts. This is due to the following effects: additives of a certain amount of unheated solid materials having the same composition as the alloy introduced into the superheated melt and being melted, acting as melting microcoolers, and by creating a modifying effect for the structure, introducing a large number of potential crystallization centers [41]. In the ideal case, when using the technology of thermal-rate processing to fix the effect of overheating, it is advisable to use additives of fine-grained materials, for example, waste and return of die casting of an alloy of the appropriate composition, or a specially prepared charge blank. In this case, smallscale microheterogeneities contribute to the intensification of the process of obtaining fine-grained structural components of the alloy.

In addition, high-temperature overheating and isothermal holding can lead to the activation of various insoluble particles (for example, oxide inclusions of $\mathrm{Al}_{2} \mathrm{O}_{3}$ and $\mathrm{MgO}$, spinels, etc.), which are always present in aluminum melts in certain quantities and are not wetted by melts under normal melting and casting conditions. In particular, overheating increases the wettability of alumina particles [42], which allows them to act as a substrate for the nucleation of crystals of $\alpha$-solid solution. An increase in the wettability of oxide inclusions can also be caused by polymorphic transformations of aluminum oxide. At temperatures above $800^{\circ} \mathrm{C}$, aluminum oxide undergoes polymorphic transformations from $\gamma-\mathrm{Al}_{2} \mathrm{O}_{3}$ to $\delta-\mathrm{Al}_{2} \mathrm{O}_{3}$ [43]. Thus, aluminum oxide, together with other insoluble particles, can be involved in the crystallization process, although under normal conditions of melting and 
casting, it does not participate directly in it. The stated assumptions lead to the conclusion about the possibility of a complex effect of overheating on the state of metal melts.

Thus, overheating treatment with rapid melt cooling is one of the most simple and effective ways to obtain a fine-grained cast structure of alloys with a more uniform distribution of alloying elements, which has a positive effect on the micro- and macrostructure of castings and, as a consequence, on the resulting level of mechanical properties. Despite some limitations associated with an increase in energy consumption, an increase in the duration of the technological cycle and a reduction in the service life of the crucible, the effectiveness of the modifying effect on the structure of alloys during overheat treatment in many cases is not lower than when using traditional grain refiners of chemical action, which is confirmed by the results of early studies, for example [32]. In addition, the modifying effect of the overheat treatment is especially relevant for improving the quality of alloys when using their return, scrap and waste, and secondary charge materials. However, despite numerous scientific results, many questions remain regarding the mechanisms of the effect of high-temperature overheating on the structure and properties of aluminum casting alloys. Therefore, it is necessary to continue comprehensive research in this direction, including those promoting the development of a general theory of modification of alloys and its relationship with the representations about the structure of metal melts.

\section{Conclusions}

Experimental studies have made it possible to establish the effect of different levels of melt overheating with subsequent fast cooling down to the pouring temperature on the formation of a cast microstructure and mechanical properties of AA 511 aluminum alloy, which belongs to the Al-Mg-Si system. Metallographic studies of alloy specimens in the cast state, obtained at different temperatures of the melt overheating, have confirmed the strong modifying effect on the dispersion and morphology of structural components. In particular, an increase in the temperature of the melt overheating to $900{ }^{\circ} \mathrm{C}$ was accompanied by refining of dendrite cells of an aluminum $\alpha$-solid solution on average to $\sim 13 \mu \mathrm{m}$ (more than three times in comparison with the initial state). It was also followed with a decrease in the size of eutectic inclusions of the $\mathrm{Mg}_{2} \mathrm{Si}$ phase and a change in their morphology to more compact. Analysis of the distribution of elements according to EDS line scans showed an increase in the degree of saturation of the aluminum matrix with magnesium with an increase in the overheating temperature. The application of the melt overheating technique and fast melt cooling contributed to a significant increase in the mechanical properties of AA 511 alloy. In particular, the maximum values of tensile strength and elongation reached $228 \mathrm{MPa}$ and $5.24 \%$, respectively, when the melt was overheated to $900^{\circ} \mathrm{C}$.

Author Contributions: Conceptualization, V.D. and E.P.; methodology, X.C.; formal analysis, V.D. and S.K.; investigation, V.D., E.P. and S.S.; writing — original draft preparation, V.D. and E.P.; writingreview and editing, E.R., O.P. and S.K.; project administration, S.K.; funding acquisition, V.D. All authors have read and agreed to the published version of the manuscript.

Funding: This research was funded by the Russian Science Foundation (project no. 20-19-00687).

Data Availability Statement: The data presented in this study are available on request from the corresponding author. The data are not publicly available due to restrictions, as the research is ongoing.

Conflicts of Interest: The authors declare no conflict of interest. The funders had no role in the design of the study; in the collection, analyses, or interpretation of data; in the writing of the manuscript, or in the decision to publish the results.

\section{References}

1. Lumley, R. (Ed.) Fundamentals of Aluminium Metallurgy: Recent Advances, 1st ed.; Woodhead Publishing: Sawston, UK, 2018.

2. Du, J.; Wen, B. Composition-structure-property correlations of complex metallic alloys described by the "cluster-plus-glue-atom" model. Appl. Mater. Today 2017, 7, 13-46. [CrossRef]

3. Staszczyk, A.; Sawicki, J.; Adamczyk-Cieslak, B. A Study of Second-Phase Precipitates and Dispersoid Particles in 2024 Aluminum Alloy after Different Aging Treatments. Materials 2019, 12, 4168. [CrossRef] 
4. Sigworth, G.K.; Kuhn, T.A. Grain refinement of aluminum casting alloys. Int. J. Metalcast. 2007, 1, 31-40. [CrossRef]

5. Easton, M.A.; Qian, M.; Prasad, A.; St. John, D.H. Recent advances in grain refinement of light metals and alloys. Curr. Opin. Solid State Mater. Sci. 2016, 20, 13-24. [CrossRef]

6. Guan, R.G.; Tie, D. A Review on grain refinement of aluminum alloys: Progresses, challenges and prospects. Acta Metall. Sin. 2017, 30, 409-432. [CrossRef]

7. Maung, K.N.; Yoshida, T.; Liu, G.; Lwin, C.M.; Muller, D.B.; Hashimoto, S. Assessment of secondary aluminum reserves of nations. Resour. Conserv. Recycl. 2017, 126, 34-41. [CrossRef]

8. Reck, B.K.; Graedel, T.E. Challenges in Metal Recycling. Science 2012, 337, 690. [CrossRef]

9. Deev, V.; Prusov, E.; Rakhuba, E. Physical Methods of Melt Processing at Production of Aluminum Alloys and Composites: Opportunities and Prospects of Application. Mater. Sci. Forum 2019, 946, 655-660. [CrossRef]

10. Wang, J.; He, S.; Sun, B.; Li, K.; Shu, D.; Zhou, Y. Effects of melt thermal treatment on hypoeutectic Al-Si alloys. Mater. Sci. Eng. A 2002, 338, 101-107. [CrossRef]

11. Jie, W.; Chen, Z.; Reif, W.; Müller, K. Superheat treatment of Al-7Si-0.55Mg melt and its influences on the solidification structures and the mechanical properties. Metall. Mater. Trans. A Phys. Metall. Mater. Sci. 2003, 34, 799-806. [CrossRef]

12. Li, Q.L.; Xia, T.D.; Lan, Y.F.; Li, P.F. Effects of melt superheat treatment on microstructure and wear behaviours of hypereutectic Al-20Si alloy. Mater. Sci. Technol. 2014, 30, 835-841. [CrossRef]

13. Zhang, Y.; Cheng, X.; Zhong, H.; Xu, Z.; Li, L.; Gong, Y.; Miao, X.; Song, C.; Zhai, Q. Comparative study on the grain refinement of Al-Si alloy solidified under the impact of pulsed electric current and travelling magnetic field. Metals 2016, 6, 170. [CrossRef]

14. Chen, H.; Jie, J.; Fu, Y.; Ma, H.; Li, T. Grain refinement of pure aluminum by direct current pulsed magnetic field and inoculation. Trans. Nonferrous Met. Soc. China 2014, 24, 1295-1300. [CrossRef]

15. Riedel, E.; Liepe, M.; Scharf, S. Simulation of Ultrasonic Induced Cavitation and Acoustic Streaming in Liquid and Solidifying Aluminum. Metals 2020, 10, 476. [CrossRef]

16. Wang, G.; Wang, Q.; Easton, M.A.; Dargusch, M.S.; Qian, M.; Eskin, D.G.; StJohn, D.H. Role of ultrasonic treatment, inoculation and solute in the grain refinement of commercial purity aluminium. Sci. Rep. 2017, 7, 9729. [CrossRef] [PubMed]

17. Kudryashova, O.; Khmeleva, M.; Danilov, P.; Dammer, V.; Vorozhtsov, A.; Eskin, D. Optimizing the conditions of metal solidification with vibration. Metals 2019, 9,366. [CrossRef]

18. Deev, V.B.; Prusov, E.S.; Kutsenko, A.I. Theoretical and experimental evaluation of the effectiveness of aluminum melt treatment by physical methods. Metall. Ital. 2018, 2, 16-24.

19. Poole, P.H.; Grande, T.; Angell, C.A.; McMillan, P.F. Polymorphic phase transitions in liquids and glasses. Science 1997, 275, 322-323. [CrossRef]

20. Zu, F.-Q. Temperature-Induced Liquid-Liquid Transition in Metallic Melts: A Brief Review on the New Physical Phenomenon. Metals 2015, 5, 395-417. [CrossRef]

21. Khalouk, K.; Mayoufi, M.; Gasser, J.G. Are there phase transitions in liquid metallic alloys? Philos. Mag. 2010, 90, 2695-2709. [CrossRef]

22. Wang, Q.L.; Geng, H.R.; Zuo, M.; Long, F.; Peng, X. Effects of melt thermal rate treatment and modification of P and RE on hypereutectic Al-Si-Cu-Mg alloy. Mater. Sci. Technol. 2013, 29, 1233-1240. [CrossRef]

23. Sheng, M.; Li, M.; Long, F.; Luo, H.; Leng, J.; Geng, H. Effects of Melt Thermal-Rate Treatment and Modification of Y on Zn-27Al Alloy. JOM 2015, 67, 991-995. [CrossRef]

24. Dahlborg, U.; Calvo-Dahlborg, M.; Eskin, D.G.; Popel, P.S. Thermal melt processing of metallic alloys. In Solidification Processing of Metallic Alloys under External Fields; Eskin, D.G., Mi, J., Eds.; Springer International Publishing: Cham, Switzerland, 2018; pp. 277-315.

25. Brodova, I.G.; Popel, P.S.; Eskin, G.I. Liquid Metal. Processing. Application to Aluminium Alloy. Production; Taylor and Francis: New York, NY, USA, 2002.

26. Deev, V.B.; Prusov, E.S.; Ri, E.H.; Smetanyuk, S.V.; Feoktistov, A.V. Improving the wear resistance of cast aluminum alloys by the melt thermal-rate treatment. J. Phys. Conf. Ser. 2020, 1679, 052011. [CrossRef]

27. Wang, Q.; Geng, H.; Zhang, S.; Jiang, H.; Zuo, M. Effects of Melt Thermal-Rate Treatment on Fe-Containing Phases in Hypereutectic Al-Si Alloy. Metall. Mater. Trans. A 2014, 45, 1621-1630. [CrossRef]

28. Wang, Q.; Zhang, S.; Zhang, Z.; Yan, X.; Geng, H. Study of Melt Thermal-Rate Treatment and Low-Temperature Pouring on Al-15\%Si Alloy. JOM 2013, 65, 958-966. [CrossRef]

29. Gomes, C.H.U.; Kikuchi, R.H.L.; Barros, A.S.; da Silva, J.N.S.; da Silva, M.A.P.S.; Moreira, A.L.S.; da Rocha, O.F.L. On the Natural Convection in the Columnar to Equiaxed Transition in Directionally Solidified Aluminum-based Binary and Multicomponent Alloys. Mater. Res. 2015, 18, 1362-1371. [CrossRef]

30. Wang, J.; He, S.X.; Sun, B.D.; Guo, Q.X.; Nishio, M. Grain refinement of Al-Si alloy (A356) by melt thermal treatment. J. Mater. Process. Technol. 2003, 141, 29-34. [CrossRef]

31. Dai, H.S.; Liu, X. Optimal holding temperatures and phosphorus additions for primary silicon refinement in Al-high Si alloys. Mater. Sci. Technol. 2009, 25, 1183-1188. [CrossRef]

32. Jia, P.; Zhang, J.; Hu, X.; Teng, X.; Zuo, M.; Gao, Z.; Yang, C.; Zhao, D. Grain refining effects of the melt thermal-rate treatment and Al-Ti-B-Y refiner in as-cast Al-9Si-0.5Mg alloy. Mater. Res. Express 2018, 5, 066520. [CrossRef] 
33. Zhou, Y.Z.; Geng, H.R.; Sun, Y.J.; Li, M. Microstructure and Mechanical Behaviors of AZ91 Magnesium Alloy with Thermal Rate Treatment Technique. Adv. Mat. Res. 2011, 306-307, 471-474. [CrossRef]

34. Deev, V.; Prusov, E.; Shurkin, P.; Ri, E.; Smetanyuk, S.; Chen, X.; Konovalov, S. Effect of La addition on solidification behavior and phase composition of cast Al-Mg-Si Alloy. Metals 2020, 10, 1673. [CrossRef]

35. Aryshnskii, E.V.; Bazhin, V.Y.; Kawalla, R. Strategy of refining the structure of aluminum-magnesium alloys by complex microalloying with transition elements during casting and subsequent thermomechanical processing. Non Ferr. Met. 2019, 1, 28-32. [CrossRef]

36. Konstantinova, N.; Kurochkin, A.; Popel, P. Viscosity and volume properties of the Al-Cu melts. EPJ Web Conf. 2011, 15, 01024. [CrossRef]

37. Popel, P.; Dahlborg, U.; Calvo-Dahlborg, M. On the existence of metastable microheterogeneities in metallic melts. IOP Conf. Ser. Mater. Sci. Eng. 2017, 192, 012012. [CrossRef]

38. Popel', P.S.; Sidorov, V.E.; Brodova, I.G.; Calvo-Dahlborg, M.; Dahlborg, U. Effect of Heat Treatment of a Melt on the Structure and Properties of the Corresponding Crystalline Ingots or Castings. Russ. Metall. 2020, 2020, 821-840. [CrossRef]

39. Jie, Z.; Zhang, J.; Huang, T.; Liu, L.; Fu, H. The influence of melt superheating treatment on the cast structure and stress rupture property of IN718C superalloy. J. Alloys Compd. 2017, 706, 76-81. [CrossRef]

40. Qin, Q.D.; Zhao, Y.G.; Liang, Y.H.; Zhou, W. Effects of melt superheating treatment on microstructure of $\mathrm{Mg}{ }_{2} \mathrm{Si} / \mathrm{Al}-\mathrm{Si}-\mathrm{Cu}$ composite. J. Alloys Compd. 2005, 399, 106-109. [CrossRef]

41. Deev, V.; Prusov, E.; Ponomareva, K. Effect of Superheat Melt Treatment on Microstructure and Mechanical Properties of Aluminum Alloys Produced by Lost Foam Casting. Solid State Phenom. 2018, 284, 593-597. [CrossRef]

42. Li, Y.; Shang, H.; Ma, B.; Guo, X.; Li, R.; Li, G. The Effect of Temperature and Sputtered Particles on the Wettability of $\mathrm{Al}_{1} \mathrm{Al}_{2} \mathrm{O}_{3}$. Materials 2021, 14, 2110. [CrossRef]

43. Lamouri, S.; Hamidouche, M.; Bouaouadja, N.; Belhouchet, H.; Garnier, V.; Fantozzi, G.; Trelkat, J.F. Control of the $\gamma$-alumina to $\alpha$-alumina phase transformation for an optimized alumina densification. Boletín Soc. Española Cerámica Vidr. 2017, 56, 47-54. [CrossRef] 